University of Nebraska - Lincoln

DigitalCommons@University of Nebraska - Lincoln

Faculty Publications from the Harold W. Manter Laboratory of Parasitology

December 2000

\title{
Phylogenetic Relationships Among Species of Stilestrongylus Freitas, Lent and Almeida, 1937 (Trichostrongyloidea: Heligmonellidae: Nippostrongylinae), Parasites of Myomorph Rodents (Rodentia: Muridae) in the Neotropics
}

\author{
Gerardo Perez-Ponce de Leon \\ Universidad Nacional Autonoma de Mexico, ppdleon@servidor.unam.mx \\ Scott Lyell Gardner \\ University of Nebraska - Lincoln, slg@unl.edu \\ Jorge Falcon-Ordaz \\ Universidad Nacional Autonoma de Mexico, falcon_jorge@terra.com.mx
}

Follow this and additional works at: https://digitalcommons.unl.edu/parasitologyfacpubs

Part of the Parasitology Commons

Perez-Ponce de Leon, Gerardo; Gardner, Scott Lyell; and Falcon-Ordaz, Jorge, "Phylogenetic Relationships Among Species of Stilestrongylus Freitas, Lent and Almeida, 1937 (Trichostrongyloidea: Heligmonellidae: Nippostrongylinae), Parasites of Myomorph Rodents (Rodentia: Muridae) in the Neotropics" (2000). Faculty Publications from the Harold W. Manter Laboratory of Parasitology. 42.

https://digitalcommons.unl.edu/parasitologyfacpubs/42

This Article is brought to you for free and open access by the Parasitology, Harold W. Manter Laboratory of at DigitalCommons@University of Nebraska - Lincoln. It has been accepted for inclusion in Faculty Publications from the Harold W. Manter Laboratory of Parasitology by an authorized administrator of DigitalCommons@University of Nebraska - Lincoln. 


\title{
PHYLOGENETIC RELATIONSHIPS AMONG SPECIES OF STILESTRONGYLUS FREITAS, LENT AND ALMEIDA, 1937 (TRICHOSTRONGYLOIDEA: HELIGMONELLIDAE: NIPPOSTRONGYLINAE), PARASITES OF MYOMORPH RODENTS (RODENTIA: MURIDAE) IN THE NEOTROPICS
}

\author{
Gerardo Pérez-Ponce de León, Scott Lyell Gardner*, and Jorge Falcón-Ordáz \\ Laboratorio de Helmintología, Instituto de Biología, UNAM, C.P. 04510 México D.F., México
}

\begin{abstract}
The phylogenetic relationships of 14 species of Stilestrongylus were analyzed using the comparative morphology of 21 characters. We obtained 2 shortest trees of 50 steps, with a consistency index of 0.540 and 25 apomorphic character states. Ingroup monophyly was supported on these trees by 2 and 3 synapomorphies, respectively, and the ingroup was defined by the following characters: greater number of ventral ridges relative to the number of ridges dorsally, asymmetric bursa, and externodorsal rays differing in size. Sister-group relationships among Stilestrongylus and the other genera designated as outgroups are relatively consistent with those postulated by Durette-Desset's in a classification of the Nippostrongylinae. The ancestor of the species groups comprising Hassalstrongylus, Guerrerostrongylus, and Stilestrongylus originated and diversified in murids in the Neotropical region. Species of Hassalstrongylus occur in rodents between southeastern North America and the eastern part of South America (Brazil and Argentina), whereas species of Guerrerostrongylus and Stilestrongylus diversified exclusively in rodents in the Neotropics.
\end{abstract}

The Nippostrongylinae Durette-Desset, 1971 includes 12 genera of trichostrongyloid nematodes parasitic in myomorph rodents (Durette-Desset, 1985). Compared with other trichostrongyloids, such as the Trichostrongylidae Leiper, 1912, the taxonomy and classification of the group has received little attention (Hoberg and Lichtenfels, 1994; Durette-Desset et al., 1999). Stilestrongylus Freitas, Lent and Almeida, 1937 in the Nippostrongylinae comprises 18 species inhabiting the small intestines of myomorph rodents in the Neotropics (Durette-Desset, 1971a, 1971b; Yoyotte, 1972; Diaw, 1976; Denke and Murua, 1977; Durette-Desset and Murua, 1979; Durette-Desset and Sutton, 1985; Sutton and Durette-Desset, 1991; Falcón-Ordáz and Sanabria, 1999). These nematodes apparently represent a monophyletic group with the following synapomorphies: synlophe with 22-28 spines of the same size, asymmetrical copulatory bursa, and hypertrophied genital cone (Durette-Desset, 1971a).

Durette-Desset $(1971 \mathrm{a}, 1985)$ postulated the existence of 3 evolutionary lines within the Nippostrongylinae. She speculated that the group originated in myomorph rodents in Southeast Asia during the upper Miocene from what she called an Orientostrongylus-like ancestor. The passage of members of the subfamily into South America occurred by the Holarctic route and involved the evolutionary line Carolinensis $\rightarrow$ Hassalstrongylus $\rightarrow$ Stilestrongylus. Species of Carolinensis (Travassos, 1937) Durette-Desset, 1983 were transferred from murid rodents to the Palearctic region and then to arvicolids in the $\mathrm{Ne}$ arctic. She speculated further that these nematodes radiated widely in arvicolid rodents and then switched rodent host families, with a lineage that we now recognize as Hassalstrongylus Durette-Desset, 1971 moving into the Neotropics from the Nearctic region in ancestors of the present Neotropical murids. She also asserted that murids moving into the northern Neotropics took species of the lineage that we recognize as Hassalstrongylus into South America in upper Pliocene time, with species

Received 16 August 1999; revised 10 April 2000; accepted 10 April 2000.

* Harold W. Manter Laboratory of Parasitology, University of Nebraska-Lincoln, W529 Nebraska Hall, Lincoln, Nebraska 68588-0514. of Stilestrongylus appearing and diversifying with South American murids (Durette-Desset, 1971a).

It appears that Durette-Desset (1971a, 1985) based her analysis on an orthogenetic perspective (see Brooks and McLennan, 1993) of the evolution of these parasites. In her analysis, she included only 2 intrinsic characters of the nematodes, i.e., copulatory bursa and synlophe, combined with extrinsic data on palaeobiogeography of the host group to argue the existence of phylogenetic or evolutionary lines and to construct a classification.

Here, we present a phylogenetic hypothesis of species included in Stilestrongylus based on a comparative analysis of strictly morphological characters. We used this phylogeny in a cladistic-biogeographical analysis of the distribution of these nematodes and their rodent hosts in the Neotropics.

\section{MATERIALS AND METHODS}

A data matrix was compiled of characters derived from comparative morphology for all 14 species in Stilestrongylus (Table I) based on published descriptions of species and specimens of 3 species from the Colección Nacional de Helmintos (CNHE), Mexico City: Carolinensis huehuetlana Falcón and Sanabria, 1996, no. 2298; S. peromysci Falcón and Sanabria, 1999, no. 2296; and S. hidalguensis Falcón and Sanabria, 1999, nos. 2293, 2294, 2295, and 2297. We consider S. aculeatum (Travassos, 1918) Durette-Desset, 1971, S. eta (Travassos, 1937) DuretteDesset, 1971, S. riberoi (Travassos, 1937) Durette-Desset, 1971, and S. stilesi Freitas, Lent, and Almeida, 1937 as species inquirendae because details of the synlophe were not given in the original descriptions and these taxa have not been redescribed.

States for each character were polarized by outgroup comparison (Watrous and Wheeler, 1981; Maddison et al., 1984) with reference to species of 4 genera of the Nippostrongylinae (Orientostrongylus, Carolinensis, Hassalstrongylus, and Guerrerostrongylus). In part, we used these representatives as outgroups to obtain information about genuslevel relationships among the 4 genera in the Nippostrongylinae, considered an evolutionary line by Durette-Desset (1985).

Plesiomorphic and apomorphic conditions for several characters are illustrated in Figures 1-8. Characters selected and character-state polarities determined after outgroup comparison were mostly consistent with previous decisions made by Durette-Desset (1971a, 1985), particularly for the synlophe and copulatory bursa. Exceptions include characters 6 and 16 (symmetrical vs. asymmetrical shape of bursa, length of the genital cone with respect to body length, respectively); for these characters we used a different coding method. 
TABLE I. Character matrix for species of Stilestrongylus and outgroups Orientostrongylus, Carolinensis, Hassalstrongylus, and Guerrerostrongylus. $?=$ missing.

\begin{tabular}{|c|c|c|c|c|c|c|c|c|c|c|c|c|c|c|c|c|c|c|c|c|c|}
\hline \multirow[b]{2}{*}{ Taxon } & \multicolumn{21}{|c|}{ Characters } \\
\hline & 1 & 2 & 3 & 4 & 5 & 6 & 7 & 8 & 9 & $\begin{array}{l}1 \\
0\end{array}$ & $\begin{array}{l}1 \\
1\end{array}$ & $\begin{array}{l}1 \\
2\end{array}$ & $\begin{array}{l}1 \\
3\end{array}$ & $\begin{array}{l}1 \\
4\end{array}$ & $\begin{array}{l}1 \\
5\end{array}$ & $\begin{array}{l}1 \\
6\end{array}$ & $\begin{array}{l}1 \\
7\end{array}$ & $\begin{array}{l}1 \\
8\end{array}$ & $\begin{array}{l}1 \\
9\end{array}$ & $\begin{array}{l}2 \\
0\end{array}$ & $\begin{array}{l}2 \\
1\end{array}$ \\
\hline Orientostrongylus & 0 & 0 & 0 & 0 & 0 & 0 & 0 & 0 & 0 & 0 & 0 & 0 & 0 & 0 & 0 & 0 & 0 & 0 & 0 & 0 & 0 \\
\hline Carolinensis & 0 & 0 & 0 & 0 & 1 & 0 & 0 & 0 & 0 & 0 & 0 & 0 & 1 & 0 & 0 & 0 & 1 & 0 & 0 & 0 & 0 \\
\hline Hassalstrongylus & 1 & 0 & 0 & 0 & 1 & 0 & 0 & 0 & 0 & 0 & 0 & 0 & 1 & 0 & 0 & 0 & 1 & 0 & 0 & 0 & 0 \\
\hline Guerrerostrongylus & 2 & 1 & 0 & 0 & 1 & 0 & 0 & 1 & 1 & 0 & 0 & 0 & 1 & 0 & 0 & 0 & 1 & 0 & 0 & 0 & 0 \\
\hline Stilestrongylus dessetae & 2 & 1 & 2 & 2 & 1 & 1 & 1 & 1 & 0 & 0 & 0 & 0 & 1 & 0 & 0 & 0 & 1 & 0 & 0 & $?$ & 0 \\
\hline S. freitasi & 2 & 1 & $?$ & 0 & 1 & 1 & 0 & 0 & 0 & 2 & 1 & 1 & 1 & 0 & 1 & 1 & 1 & 0 & 0 & $?$ & 1 \\
\hline S. inexpectatus & 2 & 1 & 0 & 0 & 1 & 1 & 0 & 0 & 0 & 2 & 1 & 1 & 1 & 0 & 1 & $?$ & 1 & 0 & 1 & $?$ & 1 \\
\hline S. barusi & 2 & 1 & $?$ & 2 & 1 & 1 & 1 & 1 & 0 & 1 & 1 & 1 & 1 & 0 & 0 & 0 & 1 & 0 & 0 & 1 & 0 \\
\hline S. renaude & 2 & 1 & 2 & 2 & 1 & 1 & 1 & 1 & 0 & 2 & 0 & 0 & 1 & 0 & 0 & 0 & 1 & 0 & 0 & 1 & 0 \\
\hline S. valdivianus & 1 & 1 & $?$ & 2 & 1 & 1 & 0 & 0 & 0 & 0 & 1 & 0 & 1 & 0 & 0 & $?$ & 1 & 0 & 0 & 0 & 0 \\
\hline S. azarai & 1 & 1 & 2 & 2 & 1 & 1 & 2 & 1 & 0 & 2 & 1 & 0 & 1 & 0 & 0 & 1 & 1 & 0 & 1 & 1 & 0 \\
\hline S. aureus & 1 & 1 & 2 & 2 & 1 & 1 & 2 & 2 & 0 & 2 & 1 & 0 & 1 & 1 & 0 & 1 & 1 & 0 & 1 & 1 & 0 \\
\hline S. manni & 1 & 1 & 2 & 2 & 1 & 1 & 0 & 2 & 1 & 0 & 0 & 1 & 1 & 0 & 0 & 1 & 1 & 0 & 0 & 1 & 0 \\
\hline S. moreli & 2 & 1 & 0 & 0 & 1 & 1 & 0 & 0 & 1 & 1 & 1 & 1 & 1 & 0 & 0 & 1 & 1 & 1 & 1 & 0 & 0 \\
\hline S. flavescens & 1 & 1 & 1 & 0 & 1 & 1 & 0 & 0 & 0 & 2 & 1 & 0 & 1 & 0 & 0 & 1 & 1 & 0 & 1 & 1 & 0 \\
\hline S. oryzomysi & 1 & 1 & 0 & 1 & 1 & 1 & 2 & 1 & 0 & 2 & 1 & 0 & 1 & 0 & 0 & 1 & 1 & 0 & 1 & 1 & 0 \\
\hline S. peromysci & 1 & 1 & 2 & 2 & 1 & 1 & 0 & 1 & 1 & 0 & 1 & 1 & 1 & 0 & 0 & 0 & 1 & 0 & 0 & $?$ & 0 \\
\hline S. hidalguensis & 1 & 1 & 2 & 1 & 1 & 1 & 2 & 2 & 1 & 0 & 0 & 1 & 1 & 0 & 1 & 0 & 1 & 0 & 1 & 1 & 1 \\
\hline
\end{tabular}

The cladistic analysis was conducted following the tenets and methods of phylogenetic systematics (Hennig, 1966; Wiley, 1981; Brooks and McLennan, 1991). All analyses were run on a Power Macintosh 8100 with PAUP 3.1.1 (Swofford, 1993) initially using the heuristic search mode with the following options: addition sequence $=$ simple; branch swapping $=$ tree bisection and reconnection (TBR), with MULPARS on. These results were confirmed with a branch-and-bound search using PAUP 4.0b2 (D. Swofford, pers. comm.) on the same machine. In all analyses, binary characters were designated as ordered, and multistate characters as unordered, with ACCTRAN optimization. Associated statistics include the consistency index (CI), rescaled consistency index (RC), retention index (RI), and homoplasy index (HI) (Swofford, 1993). To examine character evolution with respect to each of the branches in the cladogram, characters were mapped onto each of the 2 resulting trees. To examine coevolutionary associations and geographical distributions of hosts and nematodes, both host and geographic attributes were mapped onto the terminal branches of the parasite tree.

\section{RESULTS}

\section{Character analysis}

1. Ridges of synlophe-arrangement and size: Three states: $\mathbf{0}=$ synlophe with a size gradient, from right to left dorsally and from left to right ventrally (Fig. 1); $\mathbf{1}=$ absence of such a gradient with ridges of different sizes; $2=$ equal small-sized ridges (Fig. 3).

2. Total number of ridges of synlophe in males: Two states: $\mathbf{0}=$ fewer than 23 ridges; $\mathbf{1}=24$ or more ridges. Some species among the outgroup taxa have the derived condition (1 of 11 species of Orientostrongylus and 3 of 15 species of Hassalstrongylus); however, because we have no knowledge of the developmental or genetic basis of this character, we coded it as plesiomorphic for the whole outgroup based on the criterion of commonality. In addition, because species of the genus have the ancestral condition, there is no reason to assume that other species in the genus would not have a derived condition of the character in question.

3. Number of ridges dorsally versus ventrally with respect to the axis of orientation of synlophe in males: Three states: $\mathbf{0}$ $=$ greater number of ridges dorsally than ventrally; $1=$ equal number of ridges dorsally and ventrally; $\mathbf{2}=$ greater number of ridges ventrally than dorsally.

4. Number of ridges dorsally versus ventrally with respect to the axis of orientation of synlophe in females: Three states: $\mathbf{0}=$ greater number of ridges dorsally than ventrally; $\mathbf{1}=$ equal number of ridges dorsally and ventrally; $\mathbf{2}=$ greater number of ridges ventrally than dorsally.

5. Presence or absence of synlophe carene: Two states: $\mathbf{0}=$ absent (Fig. 2); 1 = present.

6. Copulatory bursa shape: Two states: $\mathbf{0}=$ symmetrical bursa; $\mathbf{1}=$ asymmetrical bursa. Some authors have classified the bursa as symmetrical, asymmetrical, and subsymmetrical. The published diagnosis of the genus Hassalstrongylus states that the bursa is either symmetrical or subsymmetrical. Two species of Stilestrongylus (S. dessetae Yoyotte, 1972 and S. renaudae Durette-Desset, 1971b) have been described as exhibiting a subsymmetrical bursa. We did not find an objective criterion to describe the subsymmetrical condition; so, in coding this character we followed Durette-Desset (1971a) and assumed that species in the genus Stilestrongylus all posses an asymmetrical bursa, relative to the body, as a general diagnostic character (Figs. 4-6).

7. Arrangement of lateral rays of copulatory bursa: In the Nippostrongylinae, 3 types of associations of lateral rays occur: $\mathbf{0}=$ type 2-2-1 in both lobes; $\mathbf{1}=$ type 1-3-1 in both lobes (i.e., S. dessetae, S. barusi Durette-Desset, 1971, and $S$. renaude); 2 $=$ different arrangements of rays in both lobes, with the 2-2-1 type in 1 and a 2-3 type in the other (i.e., S. azarai Durette- 
Desset and Sutton, 1985, S. aureus Durette-Desset and Sutton, 1985, S. oryzomysi Sutton and Durette-Desset, 1991, and S. hidalguensis) (Figs. 4-6).

8. Size of ventral rays of copulatory bursa: Three states: 0 $=$ ray 2 larger or equal to ray 3 in both lobes; $\mathbf{1}=$ ray 2 smaller than ray 3 in both lobes; $\mathbf{2}=$ different sizes of rays in both lobes (Figs. 4-6).

9. Dorsal incision of bursa with respect to lateral lobes: Two states: $\mathbf{0}=$ dorsal lobe entire with no incision; $\mathbf{1}=$ dorsal lobe divided into 2 parts by an incision (Fig. 7).

10. Position of externodorsal rays with respect to dorsal ray of bursa: Three states: $\mathbf{0}=$ externodorsal ray (either right or left) starting at base of trunk of dorsal ray; $\mathbf{1}=$ right externodorsal ray at base, and left externodorsal ray starting about $1 / 2$ to $2 / 3$ length of dorsal ray; $2=$ left externodorsal ray at base, right externodorsal ray starting about $1 / 2$ to $2 / 3$ length of dorsal ray (Figs. 7,8 ).

11. Length of externodorsal rays: Two states: $\mathbf{0}=1 \mathrm{eft}$ and right rays equal in size; $\mathbf{1}=$ rays differing in size.

12. Dorsal ray shape: Two states: $\mathbf{0}=$ dorsal ray splits into 2 symmetrical branches; $\mathbf{1}=$ dorsal ray splits into 2 asymmetrical branches.

13. Shape of the extremity of dorsal ray: Two states: $\mathbf{0}=$ extremity in form of inverted "U"; $\mathbf{1}=$ extremity in form of inverted "V".

14. Dorsal ray size with respect to total body length: Two states: $\mathbf{0}=$ ratio $1-5 \% ; \mathbf{1}=$ ratio $>6 \%$.

15. Shape of branches of dorsal ray: Two states: $\mathbf{0}=$ branches bifurcated at distal end; $\mathbf{1}=$ branches not bifurcated (Figs. 7, 8).

16. Length of genital cone with respect to total body length: Two states: $\mathbf{0}=$ ratio $<2.3 \% ; \mathbf{1}=$ ratio $2.6-4.1 \%$. DuretteDessete (1971a) considered an hypertrophied genital cone as diagnostic for species of the genus Stilestrongylus; however, we did not follow her method of coding because there are at least 5 species ( $S$. dessetae, $S$. barusi, $S$. renaude, $S$. peromysci, and $S$. hidalguensis) that have a genital cone: body length ratio of $<2.3 \%$, a condition present in species of Carolinensis, Guerrerostrongylus, and Hassalstrongylus.

17. Structure of the spicules: Two states: $\mathbf{0}=$ spicules complex, wide at base with bifurcated tip as in Orientostrongylus; $\mathbf{1}=$ spicules simple.

18. Length of spicules with respect to total body length: Two states: $\mathbf{0}=$ ratio $3-23 \% ; \mathbf{1}=$ ratio $>25 \%$.

19. Condition of caudal region of female: Two states: $0=$ nonretractile caudal region; $\mathbf{1}=$ retractile caudal region.

20. Vagina vera length with respect to total body length of female: Two states: $\mathbf{0}=$ short, $15-51 ; \mathbf{1}=1$ long, $>70$.

21. Vestibule length with respect to total body length of female: Two states: $\mathbf{1}=$ short, 30-95; 1 = long, $>100$.

\section{Phylogenetic analysis of species in the genus Stilestrongylus}

Phylogenetic analysis of the 14 taxa we consider valid using either heuristic or branch-and-bound searches resulted in 2 equally parsimonious trees of 50 steps (Figs. 9, 10). The 21 characters accounted for 25 apomorphic states with the following descriptive properties: $\mathrm{CI}=0.540, \mathrm{RC}=0.390, \mathrm{RI}=$ 0.723 , and $\mathrm{HI}=0.460$. The 2 shortest trees obtained were al-

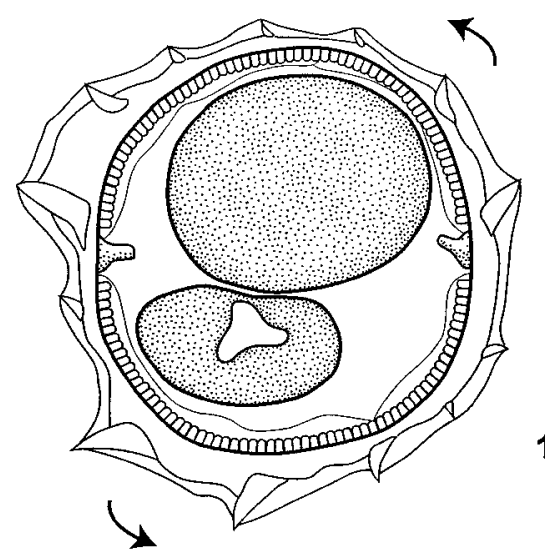

1
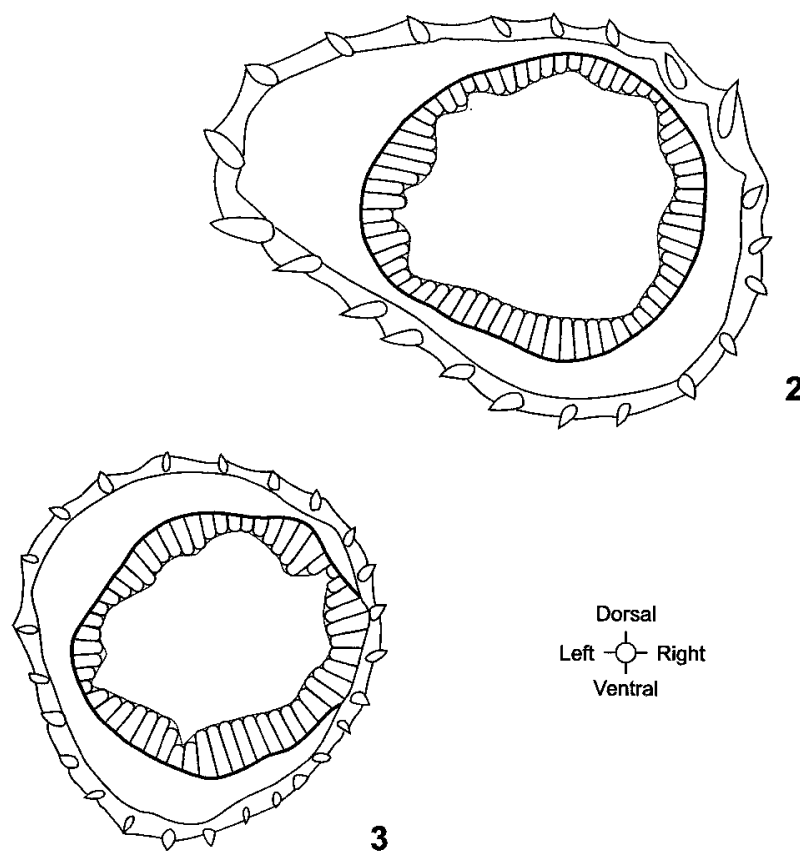

FiguREs 1-8. Characters used in the phylogenetic analysis of the species of Stilestrongylus (not to scale). Character and character states are indicated with an arrow, corresponding to character argumentation in the text. 1. Synlophe of Carolinensis kinsellai (Durette-Deset, 1969a). Cross section taken at midbody. 2. Synlophe of Hassalstrongylus epsilon (Durette-Desset, 1969b). Cross section taken at midbody. 3. Synlophe of Stilestrongylus freitasi (Durette-Desset, 1968). Cross section taken at midbody. 4. Copulatory bursa of Carolinensis peromysci (Durette-Desset, 1974). Ventral view. 5. Copulatory bursa of Stilestrongylus dessetae (Yoyotte, 1972). Ventral view. 6. Copulatory bursa of Stilestrongylus hidalguensis (Falcón-Ordáz and Sanabria, 1999). Ventral view. 7. Dorsal lobe and dorsal ray of $S$. peromysci (Falcón-Ordáz and Sanabria, 1999). 8. Dorsal lobe and dorsal ray of $S$. inexpectatus (Durette-Desset and Tchéprakof, 1969).

most identical, differing only in the position of $S$. valdivianus Durette-Desset and Murua, 1979 either as the basal member of the ingroup (Fig. 9) or as the sister of a clade composed of $S$. peromysci, S. hidalguensis, and S. manni Denke and Murua, 1977 and another clade including $S$. barusi, S. renaude, and $S$. dessetae (Fig. 10). The position of S. flavescens Sutton and Durette-Desset, 1991 is different in the 2 cladograms. In 1 (Fig. 9), S. flavescens is the sister of S. moreli Diaw, 1976, S. inex- 

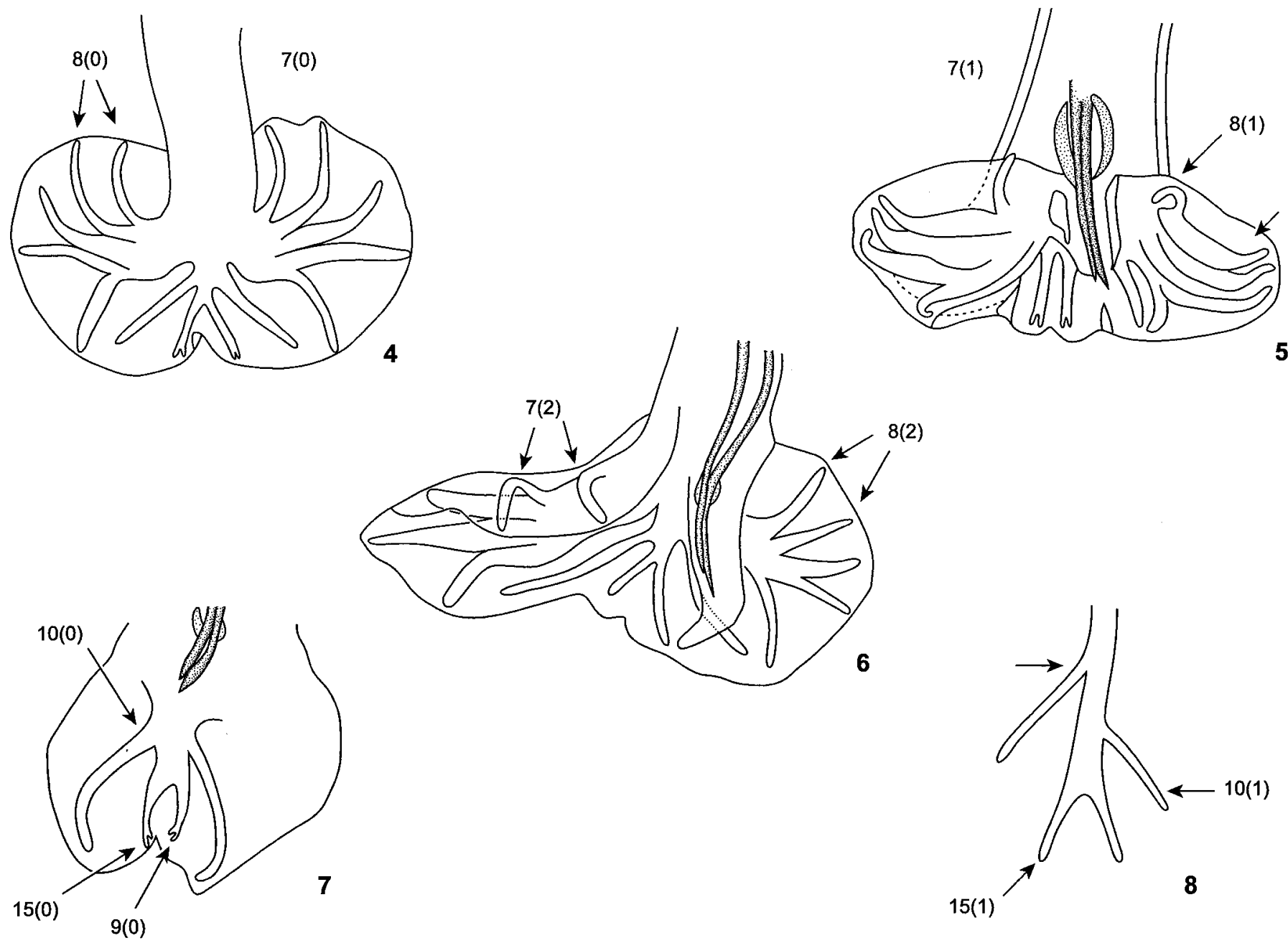

FIGURES 1-8. Continued.

pectatus Durette-Desset and Tcheprakoff, 1969, and S. freitasi Durette-Desset, 1968. In the other (Fig. 10), S. flavescens is the sister of a clade formed by $S$. oryzomysi, $S$. aureus, and $S$. azarai.

The tree was rooted using Orientostrongylus as the designated outgroup, with the analysis placing sequentially Carolinensis and then Hassalstrongylus, with Guerrerostrongylus as the sister taxon of the ingroup (Figs. 9, 10).

The monophyly of the ingroup is supported by 3 synapomorphies in Fig. 9 and 2 syapomorphies in Fig. 10, thus providing unequivocal definition of the ingroup by characters 4,6 , and 11 (greater number of ventral than dorsal ridges, asymmetrical bursa, and externodorsal rays differing in size, respectively).

Levels of homoplasy, as illustrated by the overall HI (0.460) and the CI for each character (not shown) are somewhat high, indicating that a relatively large number of characters used may show evolutionary parallelisms, convergences, or reversals in character states. Postulated homoplasies were evenly distributed throughout the cladograms, with approximately $47 \%$ restricted to the terminal taxa and $53 \%$ to hypothetical ancestors, with some monophyletic groups supported partially or entirely by homoplastic characters (Figs. 9, 10).

\section{DISCUSSION}

\section{Character evolution}

Our results show that this group of nematodes is monophyletic. Given this assumption, we present a testable hypothesis of the evolutionary and biogeographic history of these parasitic nematodes.

Hoberg and Lichtenfels (1994) presented a cladistic analysis of the Trichostrongyloidea, including 6 subfamilies of the Trichostrongylidae, using 22 morphological characters for which they obtained a single tree $(\mathrm{CI}=0.74)$. Their results were foundational, providing a rigorous assessment of the relationships of the hosts, habitats, and biogeography among the various species and groups of the Trichostrongyloidea. More recently, Durette-Desset et al. (1999) published a phylogenetic analysis of the 40 genera included within the Trichostrongyloidea where some of the results obtained by Hoberg and Lichtenfels (1994) were tested, particularly those related to the classification of the group.

In contrast to the studies of Hoberg and Lichtenfels (1994) and Durette-Desset et al. (1999), which were performed from the "top down," our analysis was performed from the "bottom up," and we found higher levels of homoplasy among charac- 


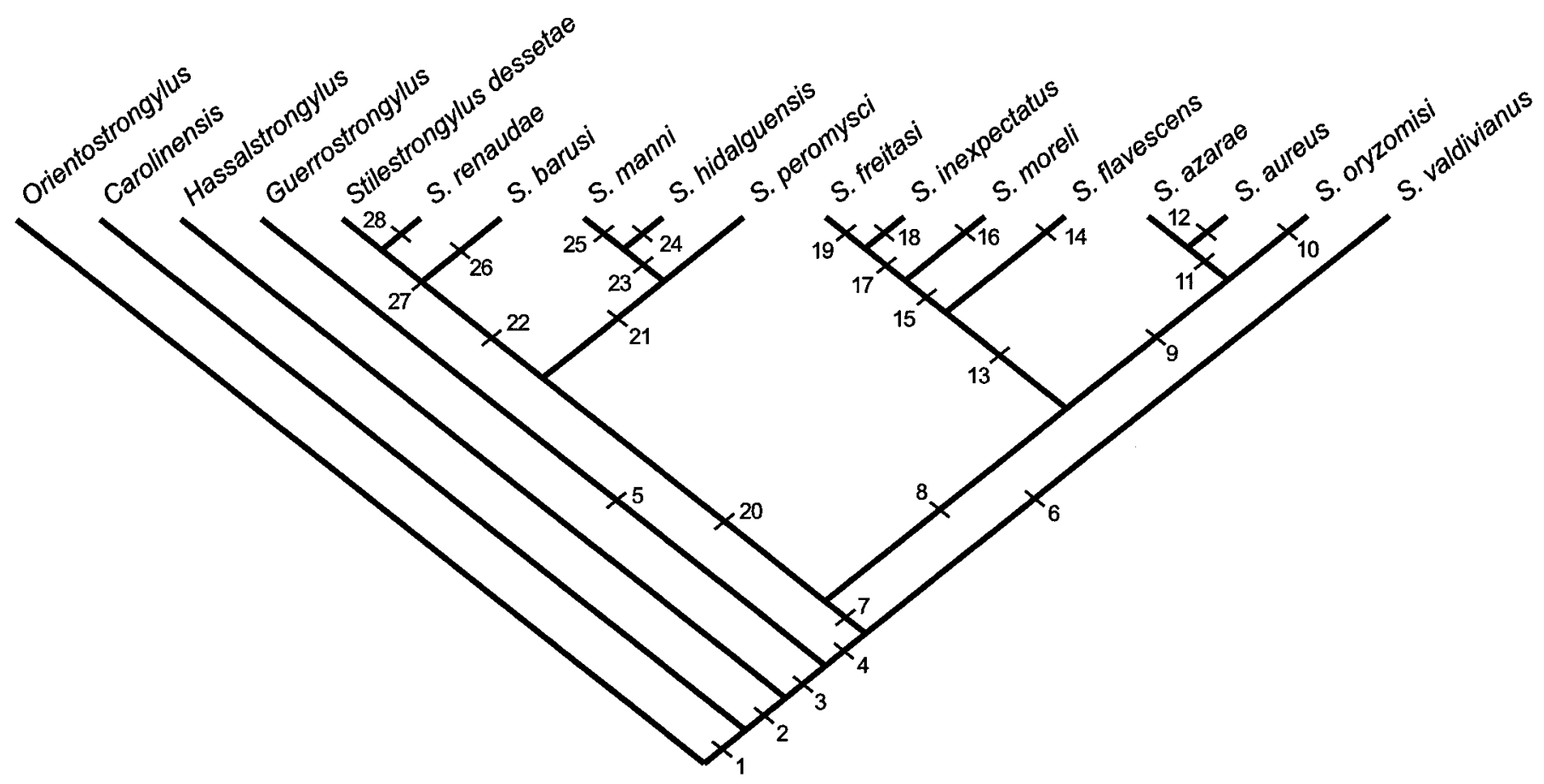

FIGURE 9. Tree showing the phylogenetic relationships among species of Stilestrongylus. Numbers mapped onto the tree are consistent with character argumentation presented in the text and data matrix (Table I). Characters and character states are included for the ingroup taxa and their sister taxa. Homoplasies are noted by asterisks (convergence or parallelism) or daggers (reversals). 1: 5(1), 13(1), 17(1); 2: 1(1); 3: 2(1), 8(1); 4:

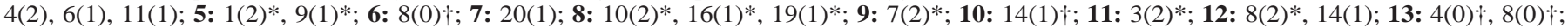
14: 3(1); 15: 1(2)*, 12(1)*, 20(0)†; 16: $9(1)^{*}, 10(1) \dagger, 18(1) ; 17: 15(1)^{*} ; 18: 24(1)^{*} ; 19: 19(0) \dagger ; 20: 3(2)^{*}, 12(1)^{*} ; 21: 9(1)^{*} ; 22: 1(2)^{*}, 7(1)$; 23: $8(2)^{*}, 11(0) \dagger ; 24: 4(1) \dagger, 7(2)^{*}, 15(1)^{*}, 19(1)^{*}, 21(1)^{*} ; 25: 16(1)^{*} ; 26: 10(1) ; 27: 11(0) \dagger, 12(0) \dagger ; 28:$ 10(2)*. Summary properties of the cladograms: $\mathrm{CI}=0.540 ; \mathrm{RI}=0.723 ; \mathrm{RC}=0.390 ; \mathrm{HI}=0.460$.

ters on our cladograms. This relatively greater level of homoplasy shows that there is probably a greater amount of adaptive plasticity of characters at the level of the species in this group of nematodes relative to the kinds of characters chosen by those authors to assess relationships at the higher levels.

Durette-Desset (1985) showed that neither cephalic structures nor characters of the reproductive system of the female could be used to formulate hypotheses of ancestor-descendant relationships in the Trichostrongyloidea. She showed that characters of the copulatory bursa and synlophe are information rich, and analysis of these characters allowed us to formulate hypotheses of the evolutionary relationships of species in the group. Even though these characters are somewhat homoplastic and exhibit various levels of evolutionary convergence, she argued that analyzing them reveals trends that allow segregation of parasites from a particular host group or from a particular biogeographic region into various evolutionary lines.

The classification, evolutionary history, and biogeographic relationships of this group of nematodes have been strongly influenced by these ideas; however, it is now widely recognized that developing explicit phylogenetic hypotheses based on the tenets of phylogenetic systematics provides biologists with the ability to make much stronger statements regarding the history of associations of groups of organisms (Brooks and McLennan, 1991, 1993). In this light, Hoberg and Lichtenfels (1994) demonstrated that Durette-Desset (1985) had a more or less orthogenetic view of evolution, this being the primary basis for the disparities between the hypothesis of Hoberg and Lichtenfels
(1994) and several competing hypotheses relative to the evolutionary relationships of the Trichostrongylidae that had been developed by Durette-Desset and colleagues since the beginning of her studies on the trichostrongylids.

The majority of the decisions concerning character argumentation in our analysis of the nippostrongylines were consistent with character sets developed by Durette-Desset (1971a, 1985), but our results are based on a formal phylogenetic analysis. Durette-Desset (1985) considered the nippostrongylines as a group of genera (with the exception of Guerrerostrongylus, which was described in 1991 ) in which the synlophe of the larvae has 3 or 4 ventral ridges and a right lateral ridge, with a total axis of orientation about $45^{\circ}$ from sagittal. Durette-Desset (1985, p. 253) postulated that the evolution of this structure can be traced in the adults beginning with Carolinensis, through Hassalstrongylus, to Stilestrongylus. According to Durette-Desset (1985), the axis of orientation of the synlophe is oblique in "primitive forms" and undergoes a rotation during the course of evolution to become frontal or subfrontal in the most "evolved" forms.

In our study, 5 of 21 characters were related to the structure of the synlophe, including arrangement and size of ridges (character 1), total number of ridges in males (character 2), number of dorsal versus ventral ridges in males (character 3), number of dorsal versus ventral ridges in females (character 4), and presence or absence of a carene (character 5). We did not code the axis of orientation as a transformation series, and no a priori assumptions were made with respect to the evolution of the synlophe (i.e., for multistate characters 1 and 3 , the states were 


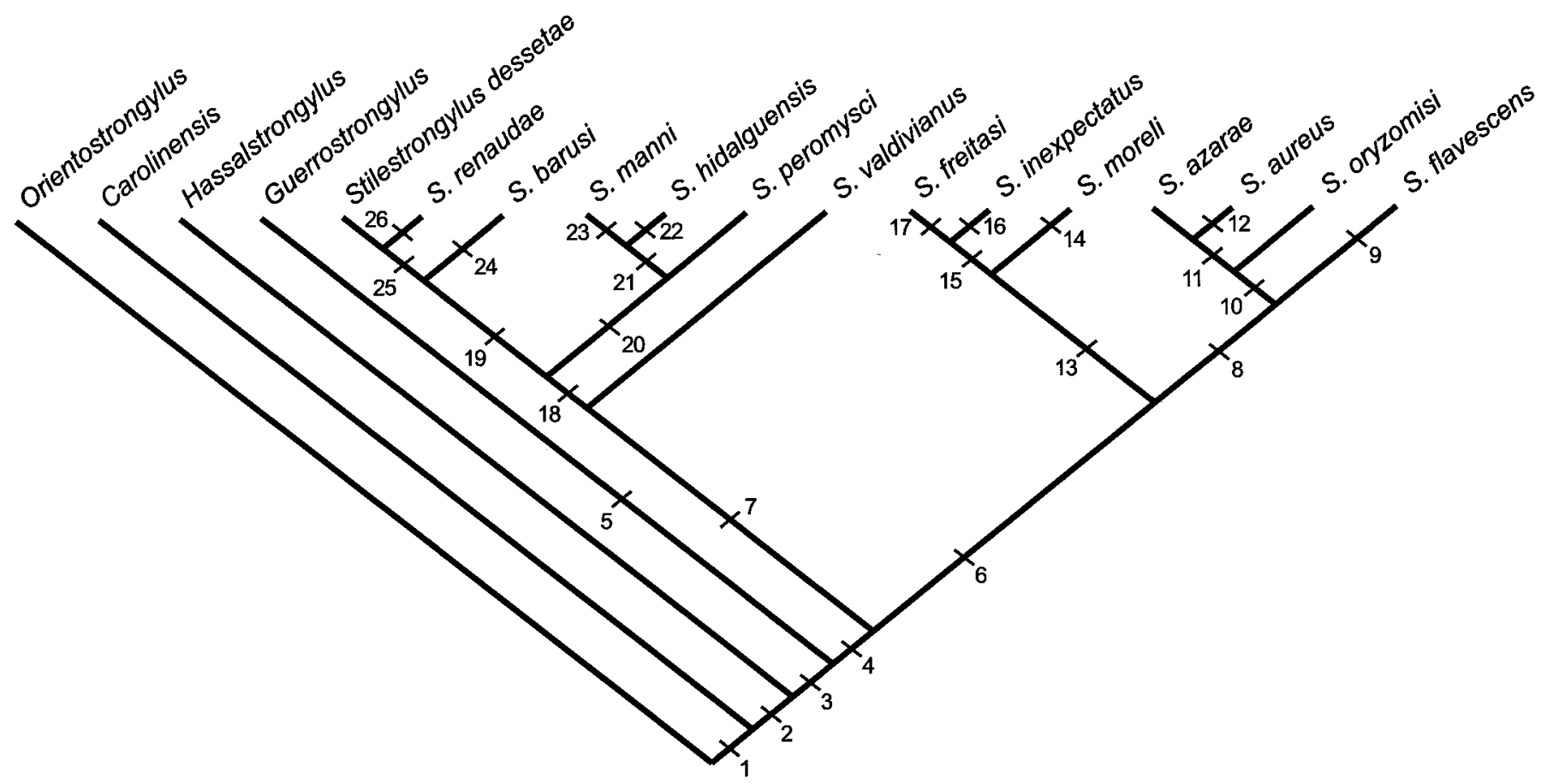

FIGURE 10. Tree showing the ancestor-descendant relationships among species of Stilestrongylus. Numbers mapped onto the tree are consistent with character argumentation presented in the text and data matrix (Table I). Characters and character states are included for the ingroup taxa and their sister taxa. Homoplasies are noted by asterisks (convergences or parallelisms) or daggers (reversals). 1: 5(1), 13(1), 17(1); 2: 1(1); 3: 2(1); 4: 6(1), 11(1); 5: 1(2)*, 8(1)*, 9(1)*; 6: 10(2)*, 16(1)*, 19(1)*; 7: 3(2)*, 4(2)*; 8: 20(1)*; 9: 3(1); 10: 4(1), 7(2)*, 8(1)*; 11: 3(2)*, 4(2)*; 12: $7(2)^{*}, 14(1) ; 13: 1(2)^{*}, 12(1)^{*} ; 14: 9(1)^{*}, 10(1) \dagger, 18(1) ; 15: 15(1)^{*} ; 16: 25(1)^{*} ; 17: 19(0) \dagger ; 18: 8(1)^{*}, 12(1)^{*}, 20(1)^{*} ; 19: 1(2)^{*}, 7(1) ; 20: 9(1)^{*} ;$ 21: $8(2)^{*}, 11(0) \dagger ; 22: 4(1) \dagger, 7(2)^{*}, 15(1)^{*}, 19(1)^{*}, 21(1)^{*} ; 23: 16(1)^{*} ; 24: 10(1) ; 25: 11(0) \dagger, 12(0) \dagger ; 26: 10(2)^{*}$. Summary properties of the cladograms: $\mathrm{CI}=0.540 ; \mathrm{RI}=0.723 ; \mathrm{RC}=0.390 ; \mathrm{HI}=0.460$.

unordered). The synlophe was shown by Durette-Desset to be 1 of the most important taxonomic characters of the Nippostrongylinae and is thought to have functional significance in locomotion and the attachment of the worm to the intestinal villi of the host (see Durette-Desset, 1985, p. 246).

\section{Host and biogeographic associations}

The idea of "evolutionary lines" in the Nippostrongylinae developed by Durette-Desset (1985) is supported in her analyses. However, her studies were based on only a few characters, which were a priori assumed to be important in delineating groups of nematodes. In addition, the "lines" hypothesis was developed using extrinsic data such as current and possible past distribution of the parasites and the host group or species in which the parasite is now found.

To focus on the phylogenetic and biogeographic analysis, we here recapitulate the main thesis of Durette-Desset (1985). She suggested that members of the Nippostrongylinae arose from a heligmonelline-like ancestor in Southeast Asia when murids appeared and then diversified in the upper Miocene. During the Pliocene, Australia, Africa, and South America each received a branch of this nematode lineage. The transfer of members of the subfamily into South America occurred by the Holarctic route and involved the evolutionary line Carolinensis $\rightarrow$ Hassalstrongylus $\rightarrow$ Stilestrongylus. Species of Carolinensis hostswitched from murid rodents in the Palearctic region to arvicolid rodents in the Nearctic. In the Nearctic region, murids were infected by a host-switch from arvicolids, and an ancestral murid then introduced the parasites (Hassalstrongylus and Guerrerostrongylus) into South America in the upper Pliocene; there, Stilestrongylus appeared and radiated in, or (perhaps more properly) with, the South American murids.

Our results show general agreement with the hypothesis of Durette-Desset (1985) in that the ancestor of the lineages of Hassalstrongylus, Guerrerostrongylus, and Stilestrongylus originated and diversified in the Neotropical region, with species of Hassalstrongylus occurring in rodents between southeastern North America and the eastern part of South America (Brazil and Argentina), whereas Guerrerostrongylus and Stilestrongylus diversified exclusively in rodents in the Neotropics.

Our results indicate 2 possible biogeographic scenarios, considering only the evolutionary history of species of Stilestrongylus. Each scenario depends on the position of S. valdivianus, either as the basal member of the group or as the sister group of a clade formed by $S$. peromysci, S. hidalguensis, S. manni, $S$. barusi, $S$. renaude, and $S$. dessetae.

\section{Host specificity (or lack thereof)}

As with species of Hassalstrongylus, species of Guerrerostrongylus and Stilestrongylus occur only in endemic Neotropical murids (with one exception). Species of Carolinensis, the sister taxon of these genera, exhibit a wider host range, occurring in representatives of many subfamilies of Muridae and species of Arvicolidae and Gerbillidae.

There appears to be some degree of host specificity among species of Stilestrongylus (Figs. 11, 12). However, there is not 


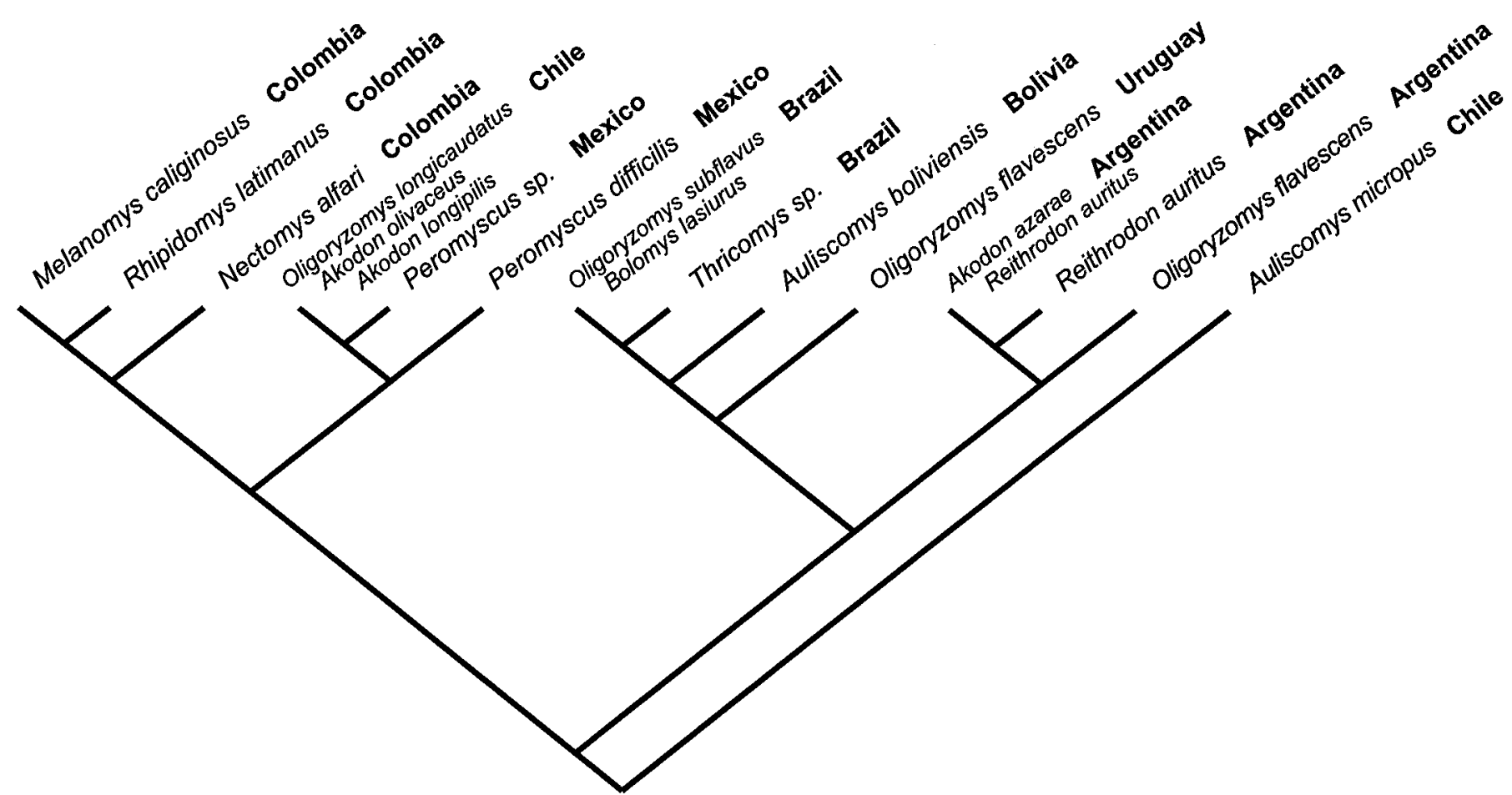

FIGURE 11. Phylogenetic tree of species of Stilestrongylus showing a hypothesis derived from the present study, associations with rodent hosts, and geographic distributions of the host and parasite mapped onto the parasite tree. Only the ingroup is shown. Stilestrongylus valdivianus (from Auliscomys micropus) is shown as the sister taxon of all other Stilestrongylus. The names of the rodents used in this figure have been updated to reflect the present state of taxonomy following Musser and Carleton (1993).

a definite pattern of cospeciation between parasites and hosts at either the specific or generic level. Our analysis shows that present patterns and associations are a result of extensive hostswitching. Some monophyletic clades of Stilestrongylus, particularly the species groups at the terminal branches of the cladogram, are found in hosts with sympatric and possibly syntopic distributions that may be phylogenetically or (and) ecologically closely related. The patterns of host and parasite associations at the level of the genus can most easily be explained as being formed by allopatric speciation events due to host-switching.

This scenario is plausible for the clade formed by $S$. renaude and $S$. dessetae $+S$. barusi; all 3 occur in the Departamento Valle de Cauca, Colombia, in Rhipidomys latimanus (Tomes), Melanomy (=Oryzomys) caliginosus (Tomes), and Nectomys alfari (Allen), respectively (Durette-Desset, 1971b; Yoyotte, 1972). Another example is the clade represented by S. oryzomisi and $S$. azarai $+S$. aureus. All 3 species were collected in different but sympatric host species in Balcarce, Buenos Aires Province, Argentina, in Akodon azarae, Oligoryzomys (=Oryzomys) flavescens, and Reithrodon auritus (see Durette-Desset and Sutton, 1985).

Our study shows that at least 2 species of mice of the genus Peromyscus from Hidalgo State in east-central Mexico, P. difficilis Allen and an unknown species of Peromyscus (the voucher specimen for the individual Peromyscus that was infected with $S$. hidalguensis was lost in an explosion at the Iztacala campus of the Escuela Nacional de Estudios Profesionales, UNAM, in 1990, but the parasites of this specimen were preserved in the Colección Nacional de Helmintos of the Institute of Biology, UNAM), are infected with 2 species of Stilestron- gylus. The area of the state of Hidalgo represents the northern limit for some Neotropical floristic elements and several species of oryzomyine rodents. Rodents of the genus Peromyscus generally reach the limits of their southern distributions through the Isthmus of Tehuantepec, although several species of Peromyscus have ranges that extend south into northern Colombia (Musser and Carleton, 1993). Our study indicates that there was a transfer of Stilestrongylus from some lineages of oryzomyines into Peromyscus during a period in which these 2 rodent lineages were sympatric/syntopic. We predict that as more species of both the peromyscine and oryzomyine lineages are examined for parasites (and other endosymbionts) from throughout their marginal ranges (both south and north, especially in Hidalgo State, Mexico), the story of host-switching and cospeciation will become much more clear. The occurrence of parasites with complex life cycles in hosts with sympatric distributions will be very strong indicators that similar ecological habitats are being used by each host lineage (Gardner and Campbell, 1992). We expect that analyses of other species of parasites from both peromyscine and oryzomyine lineages collected in the marginal forests of Hidalgo will show an emerging pattern of high biological diversity in the area.

\section{Biogeography}

When the present geographic distributions of the nematodes was optimized onto the parasite trees (Figs. 11, 12), a complex and interesting biogeographic scenario was suggested. In both cases, 2 main monophyletic lineages are evident (with the only difference represented by the position of $S$. valdivianus as sister 


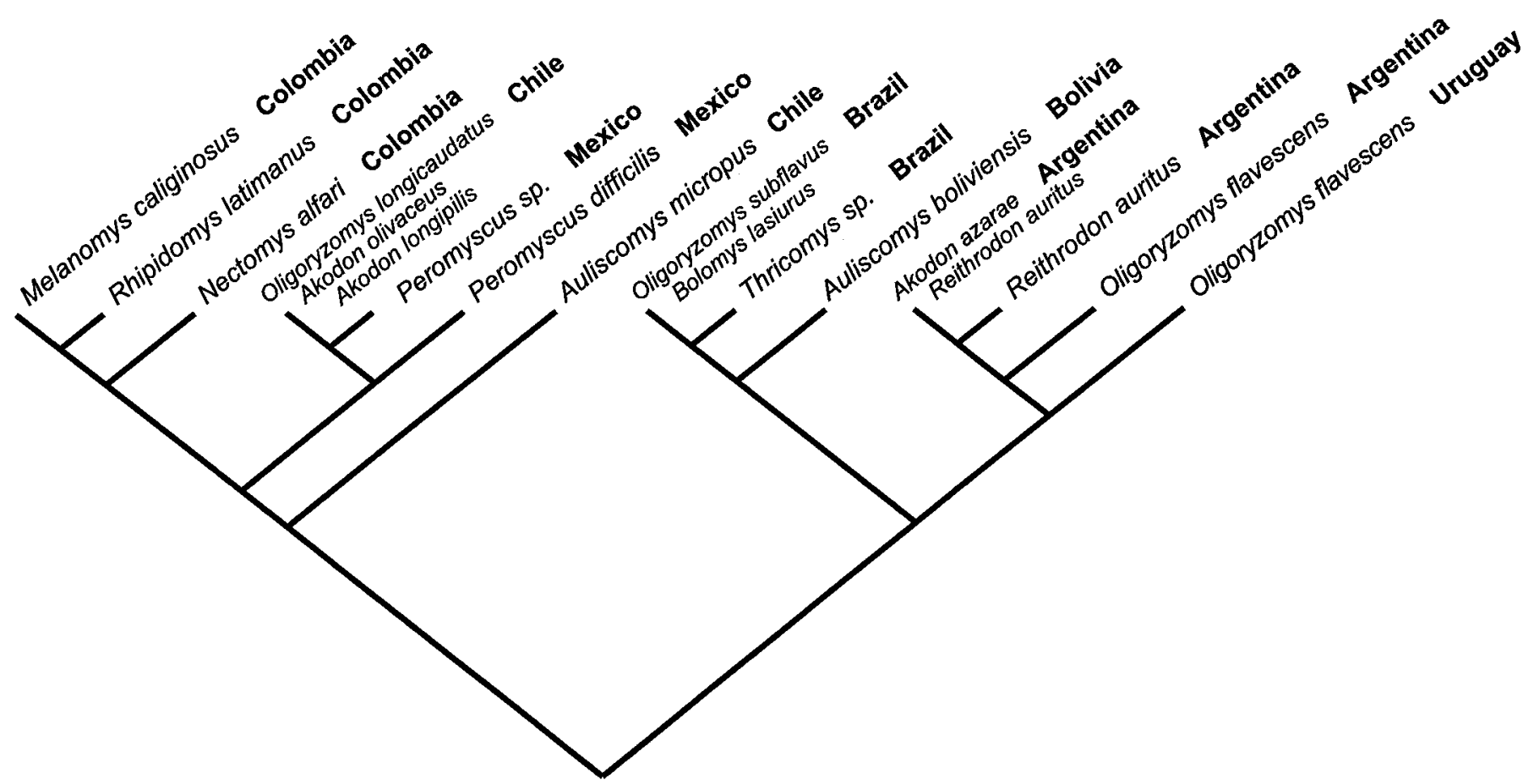

FIGURE 12. Phylogenetic tree of species of Stilestrongylus showing a hypothesis derived from the present study, associations with rodent hosts, and geographic distributions of the host and parasite mapped onto the parasite tree. Only the ingroup is shown. Stilestrongylus valdivianus (from Auliscomys micropus) is shown as a member of 1 of the subclades. The names of the rodents used in this figure have been updated to reflect the present state of taxonomy following Musser and Carleton (1993).

taxon of all other Stilestrongylus or as a member of 1 of the subclades). One lineage represents the north Neotropical region west of the Andes ( $S$. renaude, S. dessetae, S. barusi, S. hidalguensis, S. peromysci, S. manni, and S. valdivianus), with a range extending from central Mexico, south to Colombia, and further south, west of the Andes to Chile. The second lineage is formed by $S$. aureus, $S$. azarai, S. oryzomisi, S. flavescens, $S$. inexpectatus, $S$. freitasi, and $S$. moreli, representing the southeastern Neotropical region east of the Andes. Considering the present distributions of species of Hassalstrongylus, it appears that speciation in Guerrerostrongylus and Stilestrongylus was tightly coupled with the diversification of their murid hosts.

\section{Origin of murids in South America}

The origin and subsequent diversification of the Muridae in South America has been a topic of sometimes acrimonious debate for more than 30 yr (Hershkovitz, 1966; Simpson, 1980; Mares and Genoways, 1982; Slaughter and Ubelaker, 1984; Reig, 1986). South America was an island continent after contact was severed first with Africa (approximately 100 million yr ago) and then with Antarctica/Australia (approximately 7065 million yr ago) (Simpson, 1980; Pitman et al., 1993). Simpson (1980), Slaughter and Ubelaker (1984), and Marshall and Sempere (1993) have provided reviews of past and present ideas relative to the origin, evolution, and diversification of Neotropical murids (cf. cricetids).

Diversification of the South American murids may have been the result of a rapid evolution with chromosomal reorganization as a major cause of speciation (Webb, 1985). Hershkovitz $(1966,1972)$ proposed a Late Cenozoic origin and diversifica- tion of "cricetids" in northern South America and southern Central America, with a later reentrance into North America. This hypothesis postulates a South American origin of all the recent North American "cricetids" via a South American diversification of sigmodontines that rafted from Africa in the early Tertiary. Later evidence from the fossil record did not support this contention (Ferrusquia, 1978). However, circumstantial evidence may indicate that some parts of this argument are valid (Slaughter and Ubelaker, 1984; Marshall and Sempere, 1993).

Our results relative to the phylogenetic relationships among species of Stilestrongylus and the sister-taxon relationships with other Nippostrongylinae are in agreement with the hypothesis that this group of rodents has an origin in North America (Slaughter and Ubelaker, 1984). At the present time, there is no evidence to explain whether the invasion of South America and the subsequent diversification of these rodents and their parasites took place during the Pliocene, once the land connection between North and South America was established, or if it was during the Miocene, several million years earlier.

With respect to the mammalian hosts, 2 hypotheses have been proposed. The main water barrier between the 2 Americas during the period was a seaway formed by the Bolivar geosyncline that lasted into the Pliocene (Patterson and Pascual, 1972). From the latest Cretaceous (80-70 million yr ago) and during most of the Tertiary, South America was an island continent, with very low levels of interchange of mammals with other continents (the exception being the primates and the hystricognath rodents, with an arrival time of approximately 38-40 million yr ago; see Simpson, 1980). The only presently surviving 
descendants of ancestors that inhabited South America during this island phase (before 40 million yr ago) include the marsupials and the xenarthrans. Arrival of the primates and hystricognaths and finally the murid rodents on the island of South America was via 1 or several dispersal mechanisms, including rafting (a form of waif or sweepstakes dispersal) on mats of vegetation from African and North American freshwater river systems and island hopping (Hershkovitz, 1972; Simpson, 1980; Marshall and Sempere, 1993). Hershkovitz (1972) also proposed that entry of murids into South America could have occurred from Central America or through the West Indian island chain.

Terra firma gained, the newcomers ("murids" in the broad sense) diversified and spread southward, most likely along the eastern and western base of the Andes, south to the Patagonian pampas. Other murids followed uplands southward to Amazonia-Paraná and then turned east to reach the coastal highlands of Brazil. Our phylogenetic hypotheses do not demonstrate whether the invasion of the cricetids into South America was after or before the establishment of the Panamanian Land Bridge, but certainly the postulated hypotheses do not reject the alternative hypothesis to the migration routes provided by Hershkovitz (1972).

Considering both hypotheses (Figs. 11, 12), we consider that Figure 12 gives the best fit to the scenario of diversification and distribution of both nematodes and rodents that is presently seen in South America. Figure 12 shows that the ancestor of Stilestrongylus probably reached South America in the initial "murid" rodent invaders following a southerly dispersal-diversification route with an early split of the original population, 1 invading the western base of the still developing Andes (Marshall and Sempere, 1993) and the other moving along the eastern part of South America. Then, 2 lineages formed. The clade from the northern Neotropical region west of the Andes is composed of 7 species, including 2 from Mexico, 3 from Colombia, and 2 from Chile. The second clade, from the southeastern Neotropical regione east of the Andes, is represented by 7 species, including 3 from Argentina, 2 from Brazil, 1 from Bolivia, and 1 from Uruguay. Our results do not provide evidence to reject the hypothesis of Reig (1986) relative to the diversification and distribution of South American murid-sigmodontine rodents. However, the geographical distribution of species of the sister groups of Stilestrongylus (Hassalstrongylus), which have a distribution along the south and eastern part of North America south through Venezuela and Brazil, and Guerrerostrongylus, which occurs in the Amazonian region, strongly suggests that the dispersal route from North to South America may have occurred via the Western Antilles. Hershkovitz (1972) suggested that the availability and greater proximity of habitats on the Caribbean coast of Colombia and Venezuela probably favored at times the Antillean route. This may indeed have been 1 of the routes used by migrants with extant descendants that now occur mainly or entirely east of the northern Andes.

The study of other groups of helminth parasites from mammals (and other vertebrates) in the Neotropics will most certainly provide new information that will allow future researchers to develop more precise explanations of processes driving the patterns of diversification of the fauna in the Neotropical region. Because the landscape around the world is changing rapidly because of anthropogenic influences, we urge parasitol- ogists and mammalogists to work together to collect more complete data sets (including both molecular and morphological data on both hosts and parasites) while relatively natural areas and their faunas still exist.

\section{ACKNOWLEDGMENTS}

This study was partially funded by the program PAPIITUNAM grant IN219198 to G.P.P.L. and by U.S. National Science Foundation grants BSR-9024816 and DEB-9496263 to S.L.G. This study was undertaken during the sabbatical of G.P.P.L. in the H. W. Manter Laboratory (HWML) of Parasitology, University of Nebraska-Lincoln, and was funded in part by a grant to G.P.P.L. from the William C. Campbell Endowment fund supporting visiting scholars in the HWML. We thank the Dirección de Asuntos del Personal Academico-UNAM for financial support in the form of a scholarship to G.P.P.L., and we thank Angie Fox, artist for the University of Nebraska State Museum, for assistance with the figures.

\section{LITERATURE CITED}

Brooks, D. R., And D. A. McLennan. 1991. Phylogeny, ecology, and behavior: A research program in comparative biology. University of Chicago Press, Chicago, Illinois, 434 p.

— AND - 1993. Parascript: Parasites and the language of evolution. Smithsonian Institution Press, Washington, D.C., 429 p.

Denke, A. M., AND R. Murua. 1977. Description of Stilestrongylus manni n. sp. (Nematoda: Heligmosomidae) parasite de différentes Cricetides du Chili. Bulletin du Muséum d'Histoire Naturelle, 3e Série 298: 127-131.

Diaw, T. O. 1976. Contribution à l'étude de Nématodes Trichostrongyloidea parasites de Xenarthre, Marsupiaux et Rongeurs néotropicaux. Bulletin du Muséum d'Histoire Naturelle, 3e Série 282: 1065-1089.

Durette-Desset, M.-C. 1971a. Essái de classification des Nématodes Heligmosomes. Corrélations avec la paléobiogéographie des hôtes. Mémories du Muséum National d'Histoire Naturelle, Série A, Zoologie 49: 125 .

— 1971b. Nématodes Héligmosomes D’Amerique du Sud VIII. Description de six nouvelles espèces, parasites de Cricétides. Bulletin du Muséum d'Histoire Naturelle, 2e Série 42: 730-744.

- 1985. Trichostrongylid nematodes and their vertebrate hosts: Reconstruction of the phylogeny of a parasitic group. Advances in Parasitology 24: 239-306.

- J. P. Hugot, P. Darlu, and A. G. Chabaud. 1999. A cladistic analysis of the Trichostrongyloidea (Nematoda). International Journal for Parasitology 29: 1065-1086.

$\longrightarrow$, AND R. MuruA. 1979. Description de Stilestrongylus valdivianus n. sp. (Nematoda: Heligmonellidae), parasite d'un Cricetidae du Chilia. Bulletin du Muséum d'Histoire Naturelle, 4e Série 1: 245-249.

$\longrightarrow$, AND C. SuTTON. 1985. Contribución al conocimiento de la fauna parasitologica Argentina X. Nematodes (Trichostrongyloidea) en Akodon azarai azarai (Fischer) y Reithrodon auritus Fischer. Revista del Museo de La Plata (N.S.), Zoologia 151: 21-26.

FAlcón-Ordáz, J., And M. A. SAnAbria. Dos nuevas especies de Stilestrongylus Freitas, Lent y Almeida, 1937 (Nematoda: Heligmonellidae) parásitos de Peromyscus (Rodentia: Cricetidae) de México. Revista de Biologia Tropical, in press.

FERRUSQUiA, V. I. 1978. Distribution of Cenozoic vertebrate faunas in Middle America and problems of migration between North and South America. In Conexiones terrestres entre Norte y Sudamerica, V. Ferrsuquia (ed.). Boletin 101, Instituto de Geología, UNAM, México City, México, p. 193-308.

Gardner, S. L., And M. L. Campbell. 1992. Parasites as probes for biodiversity. Journal of Parasitology. 78: 596-600.

HenNig, W. 1966. Phylogenetic systematics. University of Illinois Press, Urbana, Illinois, 263 p.

Hershkovitz, P. 1966. South American swamp and fossorial rats of the 
Scapterominae group (Cricetinae, Muridae) with comments on the glans penis in murid taxonomy. Zeitschrift für Säugetierkunde 31: 81-149.

- 1972. The recent mammals of the Neotropical region: A zoogeographic and ecological review. In Evolution, mammals, and southern continents, A. Keast, F. Erk, and B. Glass (eds.). State University of New York Press, New York, New York, p. 311-431.

HoberG, E. P., AND R. Lichtenfels. 1994. Phylogenetic systematic analysis of the Trichostrongylidae (Nematoda), with an initial assessment of coevolution and biogeography. Journal of Parasitology 80: 976-996.

Maddison, W. P., M. J. Donoghue, and D. R. Maddison. 1984. Outgroup analysis and parsimony. Systematic Zoology 33: 83-103.

Mares, M. A., AND H. H. Genoways. 1982. Mammalian biology in South America, Vol. 6. Special Publication Series, Pymatuning Laboratory of Ecology, Pymatuning Symposia in Ecology, University of Pittsburg, Linesville, Pennsylvania, 539 p.

Marshall, L. G., AND T. Sempere. 1993. Evolution of the Neotropical Cenozoic land mammal fauna in its geochronologic, stratigraphic and tectonic context. In Biological relationships between Africa and South America, P. Goldblatt (ed.). Yale University Press, New Haven, Connecticut, p. 329-392.

Musser, G. G., AND M. D. Carleton. 1993. Family Muridae. In Mammal species of the world: A taxonomic and geographic reference, D. E. Wilson and D. M. Reeder (eds.). Smithsonian Institution Press, Washington, D.C., p. 501-755.

Patterson, B., AND R. PAscual. 1972. The fossil mammal fauna of South America. In Evolution, mammals, and southern continents, A. Keast, F. Erk, and B. Glass (eds.). State University of New York Press, New York, New York, p. 247-309.

Pitman, W. C., III, S. Cande, J. LaBrecque, and J. Pindell. 1993.
Fragmentation of Gondwana: The separation of Africa from South America. In Biological relationships between Africa and South America, P. Goldblatt (ed.). Yale University Press, New Haven, Connecticut, p. 14-34.

REIG, O. 1986. Diversity patterns and differentiation of high Andean rodents. In High altitude tropical biogeography, F. Vuilleumier and M. Monasterio (eds.). Oxford University Press, Oxford, U.K., p. 404-431.

Simpson, G. G. 1980. Splendid isolation, the curious history of South American mammals. Yale University Press, New Haven, Connecticut, $266 \mathrm{p}$.

Slaughter, B. H., and J. E. Ubelaker. 1984. Relationships of South American cricetines to rodents of North America and the Old World. Journal of Vertebrate Paleontology 4: 225-226.

Sutton, C., AND M.-C. DuREtTe-Desset. 1991. Nippostrongylinae (Nematoda: Trichostrongylidae) parasites d'Oryzomys flavescens en Argentine et en Uruguay. Revista Suisse du Zoologie 98: 535-553.

SwOFFORD, D. L.. 1993. PAUP: Phylogenetic analysis using parsimony, Version 3.1.1. Computer program distributed by the Illinois Natura History Survey, Champaign, Illinois

Watrous, L. E., AND Q. WheELER. 1981. The outgroup comparison method of character analysis. Systematic Zoology 30: 1-11.

WebB, D. S. 1985. Late Cenozoic mammal dispersals between the Americas. In The great American interchange, F. Stehli and D. S. Webb (eds.). Plenum Press, New York, New York, p. 357-382.

Wiley, E. O. 1981. Phylogenetics: The theory and practice of phylogenetic systematics. John Wiley and Sons, New York, New York, $439 \mathrm{p}$.

Yoyotтe, V. E. 1972. Estude de huit nématodes parasites de vertèbrés de Venezuela et de Colombie. Bulletin du Muséum d'Histoire Naturelle, 3e Série 41: 477-498. 